\title{
Enzymatic activities and kinetic properties of $\beta$-glucosidase from selected white rot fungi
}

\author{
Priscilla M. Mfombep ${ }^{1,2}$, Zachary N. Senwo ${ }^{1 *}$, Omoanghe S. Isikhuemhen ${ }^{3}$ \\ ${ }^{1}$ Department of Biological \& Environmental Sciences, Alabama Agricultural and Mechanical University, Normal, USA \\ ${ }^{2}$ Department of Agronomy, Kansas State University, Manhattan, USA \\ ${ }^{3}$ Department of Natural Resources \& Environmental Design, North Carolina A \& T State University, Greensboro, USA \\ Email: ${ }^{*}$ zachary.senwo@aamu.edu
}

Received 15 January 2013; revised 8 March 2013; accepted 15 April 2013

Copyright (C) 2013 Priscilla M. Mfombep et al. This is an open access article distributed under the Creative Commons Attribution License, which permits unrestricted use, distribution, and reproduction in any medium, provided the original work is properly cited.

\begin{abstract}
Beta-glucosidase is among the suite of enzymes produced by white rot fungi (WRF) to biodegrade plant biomass. This study investigated the enzymatic activities and kinetic properties of $\beta$-glucosidase from seventeen WRF comprised of the following species from various geographical locations: Pleurotus ostreatus, Auricularia auricular, Polyporus squamosus, Trametes versicolor, Lentinula edodes, and Grifola frondosa. All the WRF studied showed $\beta$-glucosidase activities. Significant variations in protein and carbohydrate contents were also recorded. Beta-glucosidase activities after $30 \mathrm{~min}$ of incubation ranged from $6.4 \mu \mathrm{g}(T$. versicolor) to $225 \mu \mathrm{g}$ ( $G$. frondosa). The calculated kinetic constant $\left(K_{m}\right)$ ranged from $0.47 \mu \mathrm{M}(A$. auricular-1120) to $719 \mu \mathrm{M}\left(L\right.$. edodes-7). The $V_{\max }$ depending on the kinetic transformation model ranged from $0.21 \mu \mathrm{g} \cdot \mathrm{min}^{-1}$ (T. versicolor) to $9.70 \mu \mathrm{g} \cdot \mathrm{min}^{-1}(G$. frondosa-28). Beta-glucosidase activities also exhibited $\mathrm{pH}$ optima between 3.5 and 5.0 while temperature optima were between $60^{\circ} \mathrm{C}$ and $70^{\circ} \mathrm{C}$ with some media exhibiting a secondary temperature peak at $90^{\circ} \mathrm{C}$ attributable to the presence of thermostable isoenzyme. WRF if appropriately screened and purified can be harnessed to potentially improve the bioconversion of cellulose to glucose and also facilitate efficient plant biomass biodegradation and production of useful plant bio-products.
\end{abstract}

Keywords: White Rot Fungi; $\beta$-Glucosidase; EC 3.2.1.21; Enzymatic Activities; Kinetic Properties; Plant Biomass

\section{INTRODUCTION}

White rot fungi (WRF) are microorganisms of great in-

${ }^{*}$ Corresponding author. terest that secrete complex suites of nonspecific extracellular ligninolytic enzymes, i.e., lignin peroxidase (EC 1.11.1.14), manganese peroxidase (EC 1.11.1.13), and laccase (EC 1.10.3.2) to biodegrade lignin [1] or digest substrates required for their proliferation and growth. The importance of white rot fungi has been noted in medicine [2], biodegradation of environmental wastes $[3,4]$, pollutants $[5,6]$, and in providing protein-rich foods [7]. Although cellulose and hemicellulose are biodegraded by several microbes, WRF which predominantly degrade lignin have been widely studied [8-11]. WRF have been screened for cellulase production potentials [12,13], but despite the vast amount of knowledge available on their enzymes, much is still to be understood about their specific enzymatic potential activities and kinetic properties. Enzymes involved with the biodegradation of lignocellulosic plant biomass are those of the "cellulase system", of which $\beta$-glucosidase is a constituent [14]. This is because the complete hydrolysis of cellulose to glucose requires this system of enzymes (cellulases) comprised of endoglucanases, exoglucanases (cellobiohydrolases) and $\beta$-glucosidase.

The $\beta$-glucosidase family (EC 3.2.1.21) is a widespread group of enzymes that catalyze the hydrolysis of a broad variety of glycosides [15]. While some organisms secrete either endoglucanase or $\beta$-glucosidase, in other organisms, $\beta$-glucosidase is either lacking or produced in insufficient quantities [16]. When $\beta$-glucosidase secretion is low, cellobiose accumulates instead of glucose [17]. Cellobiose accumulation acts as a feedback-inhibitor of cellulose depolymerization by endo- and exoglucanases $[18,19]$, which is a critical factor in the industrial scale conversion of cellulose to glucose [20]. This situation can be alleviated during industrial scale conversion of cellulosic biomass by exogenous incorporation of $\beta$-glucosidase enzyme. Other enzymatic parameters that influence cellulosic bioconversion include 
$\mathrm{pH}$, temperature, adsorption and presence of inhibitors [16]. The importance of $\beta$-glucosidase in industrial and environmental processes has been summarized $[21,22]$. The versatile nature of $\beta$-glucosidase relative to substrate specificity has increased its application in several environmentally-friendly biotechnological processes although individual WRF differ in their ability to produce this enzyme.

This study focused on investigating $\beta$-glucosidase activities and kinetic properties of selected WRF in submerged fermentation and the effects of different genera and geographical origins on the activities. The aim was also to enhance our understanding of the variabilities in biochemical characteristics and catalytic properties of $\beta$-glucosidase among selected fungal genera. White rot fungi showing best activities can be used individually or in combination with other organisms for plant biomass conversion to fermentable sugars and other bioproducts.

\section{MATERIALS AND METHODS}

\subsection{Reagents}

1) Coomassie Plus-The Better Bradford ${ }^{\mathrm{TM}}$ Assay Kit (Pierce Rockford, IL); 2) concentrated sulfuric acid $\left.\left(\mathrm{H}_{2} \mathrm{SO}_{4}\right) ; 3\right)$ phenol $(5 \%)$ prepared by diluting $55.6 \mathrm{~mL}$ $90 \% \mathrm{w} / \mathrm{w}$ phenol in about $800 \mathrm{~mL}$ distilled deionized $\mathrm{H}_{2} \mathrm{O}$, then adjusted to a final volume of $1 \mathrm{~L}$ with distilled deionized $\mathrm{H}_{2} \mathrm{O}$ and stored at $\left.4{ }^{\circ} \mathrm{C} ; 4\right)$ acetate buffer $(50$ $\mathrm{mM}, \mathrm{pH} 5.0$ ) prepared by dissolving $6.8 \mathrm{~g}$ sodium acetate trihydrate crystals in about $700 \mathrm{~mL}$ distilled deionized $\mathrm{H}_{2} \mathrm{O}$ then titrated to $\mathrm{pH} 5.0$ with $99 \%$ glacial acetic acid and adjusted to a final volume $(1 \mathrm{~L})$ with distilled deionized $\mathrm{H}_{2} \mathrm{O}$; 5) sodium carbonate $(0.2 \mathrm{M})$ prepared by dissolving $21.2 \mathrm{~g}$ in distilled deionized $\mathrm{H}_{2} \mathrm{O}$. Glucose standard solution prepared by dissolving $1.0 \mathrm{~g}$ anhydrous glucose (Sigma Co.) in distilled deionized water; 6) $p$-Nitrophenyl $\beta$-D-glucopyranoside ( $\beta$-PNPGLU) $\quad(5$ $\mathrm{mM})$ prepared by dissolving $1.51 \mathrm{~g}$ ( $\beta$-PNPGLU) (Sigma Chemical Co., St. Louis, MO) in about $800 \mathrm{~mL}$ sodium acetate buffer $(50 \mathrm{mM}, \mathrm{pH} 5.0)$ and adjusted to the final volume $(1 \mathrm{~L})$ with the same buffer and stored at $4{ }^{\circ} \mathrm{C}$; and 7) $p$-Nitrophenol standard solution prepared by dissolving $1.0 \mathrm{~g} p$-nitrophenol (PNP) in distilled deionized $\mathrm{H}_{2} \mathrm{O}$.

\subsection{Organisms}

White rot fungi isolates from the order Agaricales, Auriculariales and Aphylophorales (Table 1) used in this study are from the Mushroom Biology and Fungal Biotechnology Laboratory (MBFBL) at North Carolina A \& T State University, Greensboro, NC.

\subsection{Fungal Culture Conditions}

Actively growing mycelia of each isolate were carefully scraped off the surface of potato dextrose agar plates and used to inoculate $100 \mathrm{~mL}$ sterile liquid cultivation medium in $250 \mathrm{~mL}$ Erlenmeyer flask under sterile conditions. The medium was composed of $5 \mathrm{~g}$ soluble starch, $0.1 \mathrm{~g}$ yeast extract, and $10 \mathrm{~mL}$ sawdust extract and made-up to $1 \mathrm{~L}$ with distilled deionized water $\left(\mathrm{ddH}_{2} \mathrm{O}\right)$. Inoculated flasks were incubated at $23^{\circ} \mathrm{C} \pm 2{ }^{\circ} \mathrm{C}$ for 14 days after which the mycelia mat was carefully removed and the remaining liquid from each of the triplicates per strain was pooled, filtered through a $0.22 \mu \mathrm{m}$ acetate filter, then transferred into sterile bottles and kept at $4^{\circ} \mathrm{C}$ until used.

\subsection{Determination of Carbohydrate Contents}

Carbohydrate content of the filtrate was measured using the phenol-sulfuric acid method for total carbohydrate determination [23]. Briefly, $1 \mathrm{~mL}$ of each sample was placed in labeled $50 \mathrm{~mL}$ test tubes, to which $1 \mathrm{~mL}$ of $5 \%$ aqueous phenol solution was added. The mixture was then placed on ice and $2 \mathrm{~mL}$ of concentrated sulfuric acid was added, heated in a water bath at $80^{\circ} \mathrm{C}$ for $30 \mathrm{~min}$ and brought to room temperature by placing it in a water bath for $15 \mathrm{~min}$. All samples including the controls were treated in triplicates and the absorbance measured at 490 $\mathrm{nm}$ against water blank using a spectrophotometer (GENESYS 10 spectrophotometer, Model 335902P-000, Thermo Electron Corp. Madison WI). The standard curve prepared contained $0,20,40,60,80,100 \mu \mathrm{g} \cdot \mathrm{mL}^{-1}$ glucose and was also subjected to the same treatment conditions as the extracts.

\subsection{Determination of Protein Contents}

Protein concentration was determined as described by Bradford [24] using a standard test tube protocol with a working range of 100 to $1500 \mu \mathrm{g} \cdot \mathrm{mL}^{-1}$ protein concentration. Fifty $\mu \mathrm{L}$ of each WRF extract including controls in triplicates was placed in test tubes to which was added $1.5 \mu \mathrm{L}$ of the Bradford assay reagent (containing G-250 dye, methanol, and phosphoric acid and solubilizing agents in water). Each tube was thoroughly mixed by swirling for a few seconds and the mixtures incubated at room temperature for $10 \mathrm{~min}$. The absorbance of the blue color developed for the triplicates per sample was measured at $595 \mathrm{~nm}$ against water blank. A standard curve was prepared using bovine serum albumin (BSA) containing $0,25,125,250,500,750,1000,1500$, and 2000 $\mu \mathrm{g} \cdot \mathrm{mL}^{-1}$ BSA, that was subjected to the same experimental treatment conditions as the extracts.

\subsection{Determination of $\boldsymbol{\beta}$-Glucosidase Activities}

The $\beta$-glucosidase activity in extracts was assayed using $p$-Nitrophenyl- $\beta$-D-glucopyranoside ( $\beta$-PNPGLU) as substrate. Two $\mathrm{mL}$ of $5 \mathrm{mM} \beta$-PNPGLU (prepared in $50 \mathrm{mM}$ 
Table 1. Classification and sources of white rot fungi (source of mushroom extracts).

\begin{tabular}{|c|c|c|c|c|}
\hline Order & Scientific name & Common name & MBFBL $^{\#}$ & Source \\
\hline Agaricales & Pleurotus ostreatus (Jacq.) P. Kumm. & Oyster & 261 & $\begin{array}{l}\text { Wild isolate, found growing on poplar } \\
\log \text { in Greensboro, NC }\end{array}$ \\
\hline Agaricales & Pleurotus ostreatus (Jacq.) P. Kumm. & Oyster & 350 & $\begin{array}{l}\text { Wild isolate, found growing on poplar } \\
\qquad \log \text { in Liberty, NC }\end{array}$ \\
\hline Agaricales & Pleurotus ostreatus (Jacq.) P. Kumm. & Oyster & 400 & $\begin{array}{l}\text { Wild isolate, found growing on poplar } \\
\qquad \log \text { in Mount Airy, NC }\end{array}$ \\
\hline Agaricales & Lentinula edodes (Berk.) Pegler & Shiitake & 1 & Commercial strain \\
\hline Agaricales & Lentinula edodes (Berk.) Pegler & Shiitake & 4 & Commercial strain \\
\hline Agaricales & Lentinula edodes (Berk.) Pegler & Shiitake & 7 & Commercial strain \\
\hline Auriculariales & Auricularia auricular (Hook. f.) Underw. & Wood ear & 1120 & Commercial strain from China \\
\hline Auriculariales & Auricularia auricula (Hook. f.) Underw. & Wood ear & 1137 & Commercial strain from China \\
\hline Auriculariales & Auricularia $s p$. Bull. ex Juss & Wood ear & 265 & $\begin{array}{l}\text { Wild isolate from dead orange log in } \\
\text { Kenyansi, Ghana }\end{array}$ \\
\hline Polyporales & Grifola frondosa (Dicks.) Gray & Maitake & 26 & $\begin{array}{l}\text { Wild isolate, found growing on } \\
\text { oak in Asheville, NC }\end{array}$ \\
\hline Polyporales & Grifola frondosa (Dicks.) Gray & Maitake & 28 & Commercial isolate \\
\hline Polyporales & Grifola frondosa (Dicks.) Gray & Maitake & 32 & Wild isolate, from Ukraine \\
\hline Polyporales & Polyporus squamosus (Huds.) Fr. & $\begin{array}{l}\text { Pheasant's back } \\
\text { mushroom }\end{array}$ & 450 & $\begin{array}{c}\text { Culture collection of Institute of Evolution, } \\
\text { Haifa University, Israel }\end{array}$ \\
\hline Polyporales & Polyporus squamosus (Huds.) Fr. & $\begin{array}{l}\text { Pheasant's back } \\
\text { mushroom }\end{array}$ & 451 & $\begin{array}{c}\text { Culture collection of Institute of Evolution, } \\
\text { Haifa University, Israel }\end{array}$ \\
\hline Polyporales & Trametes versicolor (L.) Lloyd & Turkey tail & 120 & $\begin{array}{c}\text { Culture collection of Institute of Evolution, } \\
\text { Haifa University, Israel }\end{array}$ \\
\hline Polyporales & Trametes versicolor (L.) Lloyd & Turkey tail & 122 & $\begin{array}{l}\text { Wild isolate, found growing on Sweet gum } \\
\text { log in Greensboro, NC }\end{array}$ \\
\hline Polyporales & Trametes versicolor (L.) Lloyd & Turkey tail & 176 & Collected from Greensboro, NC \\
\hline
\end{tabular}

"MBFBL, Mushroom biology and fungal biotechnology laboratory at North Carolina A \& T State University, Greensboro, NC.

sodium acetate buffer, $\mathrm{pH} 5.0$ ) was placed in a $15-\mathrm{mL}$ centrifuge triplicate tubes to which was added $0.5 \mathrm{~mL}$ WRF extract and incubated at $37^{\circ} \mathrm{C}$ for $30 \mathrm{~min}$. The reaction was stopped using $1.5 \mathrm{~mL} 0.5 \mathrm{M} \mathrm{Na}_{2} \mathrm{CO}_{3}$ and the absorbance measured against a blank (sodium acetate) at $400 \mathrm{~nm}$ after $30 \mathrm{~min}$. Each experiment had a control consisting of substrate without enzyme that was also subjected to the same experimental conditions. A PNP standard was prepared containing $0,20,40,60,80$ and $100 \mu \mathrm{g}$ of PNP.

\subsection{Determination of Kinetic Parameters}

The kinetic parameters were assessed by estimating $\beta$ glucosidase activities at various $\beta$-PNPGLU concentrations $(0.02,0.05,0.1,0.5,1.0,1.5 \mathrm{mM})$. The MichaelisMenten constant $\left(K_{m}\right)$ and maximum reaction rate $\left(V_{\max }\right)$ were calculated using both linear and non-linear transformations of the Michaelis-Menten equation. The measurements to determine the temperature effects and temperature coefficients $\left(Q_{10}\right)$ for $\beta$-glucosidase activities were at $10^{\circ} \mathrm{C}$ intervals (between $10^{\circ} \mathrm{C}$ and $100^{\circ} \mathrm{C}$ ) while the activation energy $\left(E_{a}\right)$, was determined using the Arrhenius equation. Two milliliters of $5 \mathrm{mM} \beta$-PNPGLU (prepared in $50 \mathrm{mM}$ sodium acetate buffers at $\mathrm{pH}$ ranging from 3 to 7 in 0.5 increments) was used to assess the effects of $\mathrm{pH}$ on the $\beta$-glucosidase activities.

\section{RESULTS AND DISCUSSION}

\subsection{Protein and Carbohydrate Contents}

Growth media after the static cultivation of 17 WRF isolates spanning six fungal genera [Pleurotus, Auricularia, Polyporus, Trametes, Lentinula, and Grifola] (Table 1) were evaluated for their $\beta$-glucosidase activities. Mycelial growth resulted in the accumulation of secreted proteins in the culture media. The analyses showed significant differences at $p \leq 0.05$ in the total protein secreted (Table 2) and varied widely ranging from $68 \mu \mathrm{g} \cdot \mathrm{mL}^{-1}(P$. ostreatus-261, wild isolate from North Carolina) to 228 $\mu \mathrm{g} \cdot \mathrm{mL}^{-1}$ (Auricularia sp.-265, wild strain from Ghana). 
Table 2. Total protein and carbohydrate contents in media of various white rot fungi.

\begin{tabular}{|c|c|c|c|c|}
\hline Samples & Protein & \multicolumn{3}{|c|}{ Carbohydrate } \\
\hline$s$ & \multicolumn{4}{|c|}{$\mu \mathrm{g} \cdot \mathrm{mL}^{-1}$} \\
\hline Pleurotus ostreatus-261 & $68 \pm 12.5^{\dagger}$ & $(\mathrm{I})^{\S}$ & $65 \pm 10.0^{\dagger}$ & $(\mathrm{DE})^{\S}$ \\
\hline Pleurotus ostreatus-350 & $77 \pm 1.4$ & (IJ) & $46 \pm 6.4$ & (G) \\
\hline Pleurotus ostreatus -400 & $82 \pm 6.9$ & (HIJFGHIJ) & $44 \pm 10.0$ & (G) \\
\hline Lentinula edodes-1 & $112 \pm 5.7$ & (DEFGH) & $79 \pm 10.9$ & (C) \\
\hline Lentinula edodes-4 & $71 \pm 9.3$ & (IJ) & $53 \pm 11.2$ & (GF) \\
\hline Lentinula edodes-7 & $123 \pm 5.8$ & (DEFGH) & $70 \pm 8.9$ & (D) \\
\hline Auricularia sp.-265 & $228 \pm 74.7$ & (A) & $91 \pm 0.2$ & (B) \\
\hline Auricularia auricular-1120 & $200 \pm 45.4$ & $(\mathrm{AB})$ & $53 \pm 6.8$ & (GF) \\
\hline Auricularia auricular-1137 & $163 \pm 12.2$ & (BCD) & $48 \pm 4.6$ & (G) \\
\hline Grifola frondosa-26 & $92 \pm 6.0$ & (FGHIJ) & $59 \pm 2.5$ & $(\mathrm{EF})$ \\
\hline Grifola frondosa-28 & $121 \pm 0.3$ & $(\mathrm{DEFGH})$ & $14 \pm 9.6$ & $(\mathrm{H})$ \\
\hline Grifola frondosa-32 & $98 \pm 4.7$ & (EFJHI) & $53 \pm 8.4$ & (GF) \\
\hline Polyporus squamosus-450 & $172 \pm 9.1$ & (BC) & $64 \pm 4.6$ & (DE) \\
\hline Polyporus squamosus-451 & $144 \pm 10.6$ & $(\mathrm{CDE})$ & $108 \pm 4.6$ & (A) \\
\hline Trametes versicolor -120 & $132 \pm 19.1$ & (CDEFG) & $79 \pm 5.0$ & (C) \\
\hline Trametes versicolor -122 & $135 \pm 13.2$ & (CDEFG) & $83 \pm 1.8$ & (BC) \\
\hline Trametes versicolor-176 & $141 \pm 9.6$ & (CDEF) & $68 \pm 8.7$ & (DE) \\
\hline
\end{tabular}

${ }^{\dagger}$ Standard deviation $(\mathrm{n}=3) .{ }^{\S}$ ANOVA (Means with the same letters within the same columns are not significantly different).

Protein content in WRF enzyme production media ranging between 2.8 and $24.0 \mu \mathrm{g} \cdot \mathrm{mL}^{-1}$ have been reported [25], which are lower compared to this study, probably because of differences in the organisms used and the composition of the growth media. The media also had significant differences at $p \leq 0.05$ in the carbohydrate content (Table 2) which ranged from $44 \mu \mathrm{g} \cdot \mathrm{mL}^{-1}(P$. ostreatus-400) to $108 \mu \mathrm{g} \cdot \mathrm{mL}^{-1}$ (P. squamosus-451). However, there were differences in the carbohydrate contents both within and between the various genera in this study, indicating that the abundance of carbohydrate in the media is species and origin specific. The results also indicate that the carbohydrate contents of the liquid media were more variable than the protein contents.

\subsection{Beta-Glucosidase Activities}

Beta-glucosidase activities, estimated as PNP released after 30 min of incubation with $\beta$-PNPGLU at $37^{\circ} \mathrm{C}$ indicated that $G$. frondosa-28 (commercial isolate) exhibited the highest activities. Trametes versicolor-122 (wild isolate from $\mathrm{NC}$ ) showed the least total $\beta$-glucosidase activities; however, there were wide ranges in $\beta$-glucosidase activities within each genus, except in the Pleurotus strains. The range of $\beta$-glucosidase activities meas- ured within genera after $30 \mathrm{~min}$ of incubation were; Pleurotus (10.3 - $12.5 \mu \mathrm{g})$, Grifola (39.1 - $225 \mu \mathrm{g})$, Lentinula (7.2 - $22.6 \mu \mathrm{g})$, Auricularia (16.1 - $24 \mathrm{ug})$, Polyporus $(15-21 \mu \mathrm{g})$, and Trametes $(6.4-41.6 \mu \mathrm{g})$. There were also differences in $\beta$-glucosidase activities between genera ranging from 6.4 (T. versicolor-122) to $225 \mu \mathrm{g}$ ( $G$. frondosa-28). Morais et al. [26], noted marked differences in $\beta$-glucosidase activities of $L$. edodes strains, which resulted from changes in enzyme production as the duration of fermentation increased. In this study the cultivation conditions were similar for all the genera; however, differences in activities could have only resulted from the differences in the amount of $\beta$-glucosedase enzyme protein secreted. Also, variations could be at the molecular level of gene organization which influences the enzyme response to such variables as: $\mathrm{pH}$, temperature, ionic strength, and substrate-enzyme interactions in the reaction media.

Beta-glucosidase activities were not correlated with the protein contents possibly because protein in the crude extracts could include other proteins not associated with $\beta$-glucosidase activities. The variations in crude secretions could be explained by the fact that the protein contents of the extracts included other enzymes and amino 
acids not related to the enzyme activities under investigation. It has been reported that when enzymes are assayed from crude extracts, the results may not suggest a complete degradation or hydrolysis of the substrate [27]. In this study, any substrate degradation which was not the result of enzymatic activities was eliminated using controls. Beta-glucosidase activities showed significant negative correlations with carbohydrate contents which may be explained by the fact that less $\beta$-glucosidase is produced when higher available carbon is present in the medium. Also the fungi might have been taking up and assimilating the simple sugars released due to the enzymatic activities.

\subsection{Kinetic Parameters}

All the fungal $\beta$-glucosidase activities assayed fitted the Michaelis-Menten kinetic model (plots not shown) which has been reported to account for the kinetic properties of several enzymes. The Michaelis-Menten constant $K_{m}$ (indicative of enzyme-substrate affinity) and $V_{\max }$ (maximum velocity at enzyme saturation) for $\beta$-glucosidase activities in the media were calculated using both the linear and non-linear regression fit of the Michaelis-Menten equation. The average $K_{m}$ value using the three linear transformations ranged from 0.47 (A. auricula-1120) to $719 \mu \mathrm{M}$ (L. edodes-7), while $V_{\max }$ ranged from $0.21 \mu \mathrm{g} \cdot \mathrm{min}^{-1}$ (T. versicolor-122) to $9.63 \mu \mathrm{g} \cdot \mathrm{min}^{-1}$ (G. frondosa-28). The lower $K_{m}$ values usually indicate higher enzyme-substrate affinity [28]. The three transformations (Table 3) showed considerable variations, because each transformation gives different weight to errors in the variables [29]. A non-linear regression fit was also used, which gave $K_{m}$ values ranging from 0.51 $\mu \mathrm{M}$ (A. auricular-1120) to $660 \mu \mathrm{M},($ L. edodes-7), and $V_{\max }$ values ranging from $0.21 \mu \mathrm{g} \cdot \mathrm{min}^{-1}(T$. versicolor-122) to $9.70 \mu \mathrm{g} \cdot \mathrm{min}^{-1}$ (G. frondosa-28) (Table 3). Purified $\beta$-glucosidase from straw mushroom has shown $K_{m}$ values for $\beta$-PNPGLU between 90 and $500 \mu \mathrm{M}$ [30], while Sun et al. [31], reported apparent $K_{m}$ between 347 and $70 \mu \mathrm{M}$ from purified fruiting bodies of $L$. edodes. Therefore $\beta$-glucosidase from A. auricula-1120 had an affinity almost 1300 times greater for PNPGLU than $L$. edodes-7. The maximum velocity at enzyme saturation was about 45 times higher for Grifola-28 than $T$. versicolor-122. These ranges in $K_{m}$ and $V_{\max }$ indicated great disparity with which enzymes from various WRF function to biodegrade substrate.

Table 3. Kinetic parameters of $\beta$-glucosidase activities of white rot fungi calculated from different linear and non-linear transformations of the Michaelis-Menten equation.

\begin{tabular}{|c|c|c|c|c|c|c|c|c|}
\hline \multirow[b]{2}{*}{ Species } & \multicolumn{2}{|c|}{ Lineweaver-Burk } & \multicolumn{2}{|c|}{ Hanes-Wolf } & \multicolumn{2}{|c|}{ Eddie-Hofstee } & \multicolumn{2}{|c|}{ Non-linear regression } \\
\hline & $V_{\max }$ & $K_{\mathrm{m}}$ & $V_{\max }$ & $K_{\mathrm{m}}$ & $V_{\max }$ & $K_{\mathrm{m}}$ & $V_{\max }$ & $K_{\mathrm{m}}$ \\
\hline Pleurotus ostreatus-261 & 0.42 & 20 & 0.50 & 55.7 & 0.44 & 23.6 & 0.48 & 39.9 \\
\hline Pleurotus ostreatus-350 & 0.41 & 15.1 & 0.48 & 41.1 & 0.43 & 17.3 & 0.46 & 27.2 \\
\hline Pleurotus ostreatus-400 & 0.34 & 17 & 0.41 & 50.7 & 0.36 & 19.5 & 0.39 & 31.9 \\
\hline Lentinula edodes-4 & 0.24 & 4.35 & 0.25 & 11.4 & 0.24 & 4.46 & 0.24 & 4.74 \\
\hline Lentinula edodes-7 & 0.75 & 566 & 0.80 & 719 & 0.76 & 591 & 0.78 & 660 \\
\hline Lentinula edodes-1 & 0.65 & 322 & 0.66 & 362 & 0.65 & 328 & 0.66 & 346 \\
\hline Auricularia sp.-265 & 0.65 & 5.69 & 0.70 & 20.7 & 0.66 & 6 & 0.66 & 6.97 \\
\hline Auricularia sp.-1120 & 0.80 & 0.47 & 0.88 & 4.64 & 0.80 & 0.49 & 0.80 & 0.51 \\
\hline Auricularia sp.-1137 & 0.54 & 6.28 & 0.53 & 4.69 & 0.54 & 6.23 & 0.54 & 6.17 \\
\hline Grifola frondosa-26 & 0.88 & 44.6 & 1.56 & 205 & 1.14 & 69.1 & 1.59 & 253 \\
\hline Grifola frondosa-28 & 7.50 & 159 & 9.63 & 253 & 8.90 & 206 & 9.70 & 273 \\
\hline Grifola frondosa-32 & 1.30 & 628 & 1.28 & 580 & 1.30 & 623 & 1.30 & 614 \\
\hline Polyporus squamosus-450 & 0.70 & 20.2 & 0.78 & 43.5 & 0.72 & 22.4 & 0.74 & 28 \\
\hline Polyporussquamosus-451 & 0.51 & 14.6 & 0.52 & 19.3 & 0.51 & 15.08 & 0.51 & 15.9 \\
\hline Trametes versicolor-120 & 0.29 & 3.15 & 0.36 & 22.2 & 0.30 & 3.67 & 0.32 & 0.61 \\
\hline Trametes versicolor-122 & 0.21 & 0.74 & 0.24 & 5.28 & 0.21 & 0.78 & 0.21 & 0.82 \\
\hline Trametes versicolor-176 & 1.39 & 455 & 1.52 & 700 & 1.40 & 478 & 1.44 & 546 \\
\hline
\end{tabular}

$V_{\max }\left(\mu \mathrm{g} \cdot \min ^{-1}\right) ; K_{m}(\mu \mathrm{M})$. Numbers next to each species are assigned identification by Mushroom Biology and Fungal Biotechnology Laboratory (MBFBL). 


\subsection{Effects of $\mathrm{pH}$ and Temperature}

The $\mathrm{pH}$ profile of each fungal cultivation media for $\beta$-glucosidase activities showed that the extracts exhibited $\mathrm{pH}$ optima between 3.5 and 5.0 (Figure 1). Almost all displayed relative stability around their $\mathrm{pH}$ optima with the exception of $P$. ostreatus-400 and P. squamosus-451. Similar $\mathrm{pH}$ ranges have been reported for other fungal $\beta$-glucosidase activities. Previous studies have reported $\mathrm{pH}$ optima ranging between 3.8 and 5.0 for Thermoascus aurantiacus $\beta$-glucosidase activities [32] and between 4.0 and 6.0 for Aspergillus oryzae [22]. Enzymes, like all proteins are affected by changes in temperature which are used to characterize and evaluate

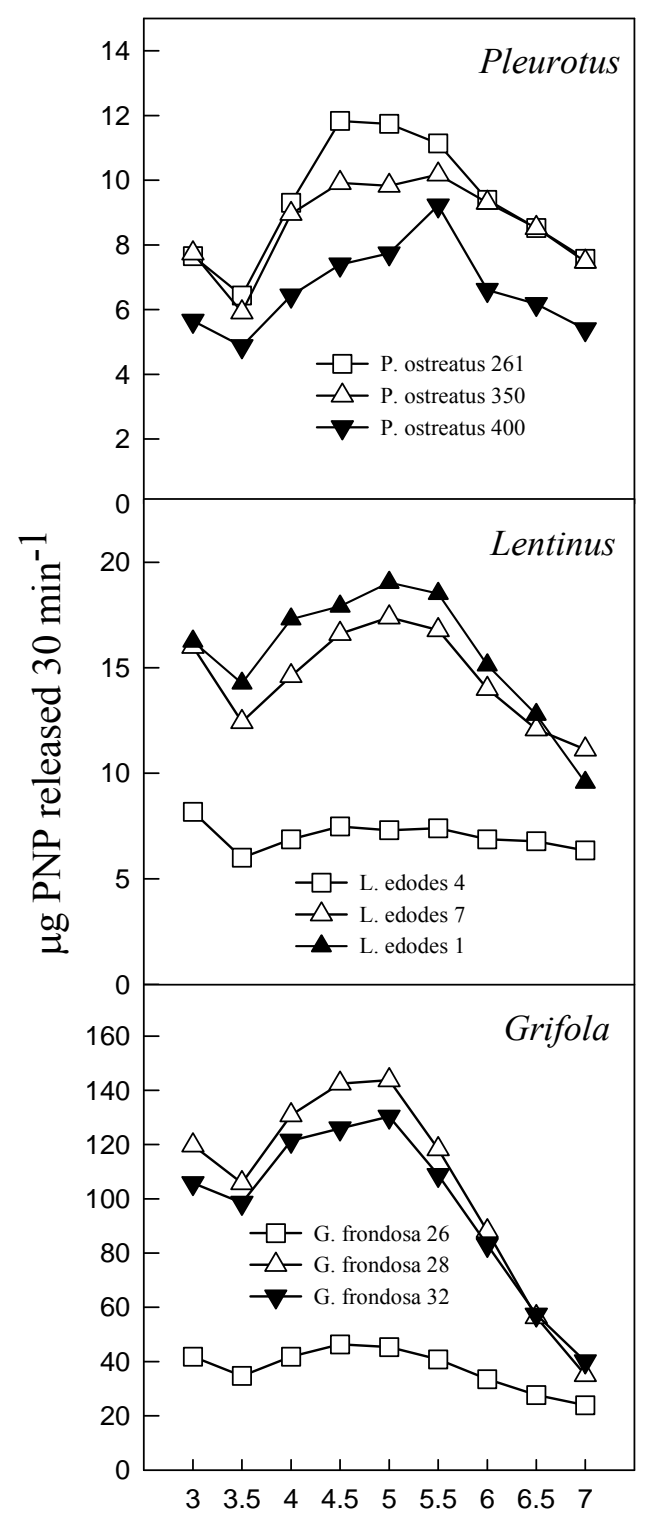

their usefulness in certain processes. Under the experimental conditions in this study, the activities exhibited temperature optima between $60^{\circ} \mathrm{C}$ and $70^{\circ} \mathrm{C}$ (Figure 2). Most media showed a secondary minor temperature peak around $90^{\circ} \mathrm{C}$, which could be attributed to the possible presence of thermostable isoenzymes in the media. The Auricularia spp. showed more stability around their temperature optima $\left(60^{\circ} \mathrm{C}-70^{\circ} \mathrm{C}\right)$, while the other genera were generally more sensitive around their temperature optima. The optimum temperature is within the range of those reported for some other fungal $\beta$-glucosidase enzymes $\left(80^{\circ} \mathrm{C}\right.$ for Thermoascus aurantiacus and $60^{\circ} \mathrm{C}$ for Aspergillus oryzae) [22].

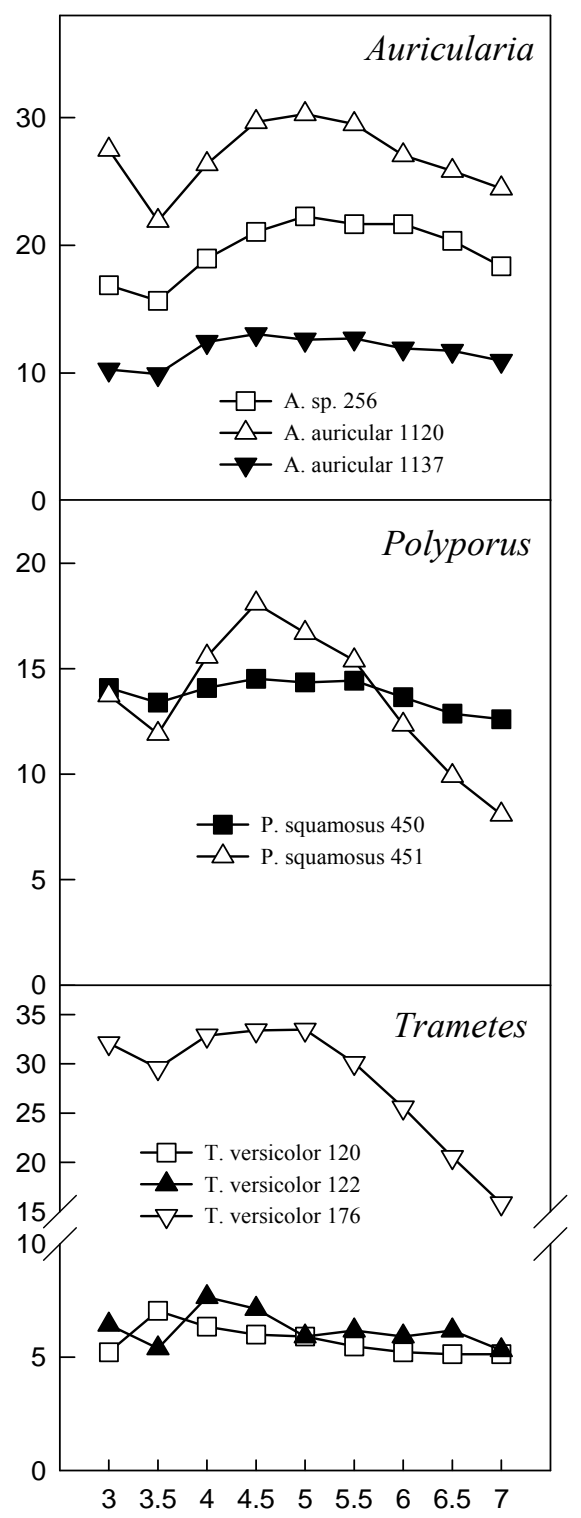

$\mathrm{pH}$

Figure 1. Effect of $\mathrm{pH}$ on $\beta$-glucosidase activities of various white rot fungi. 

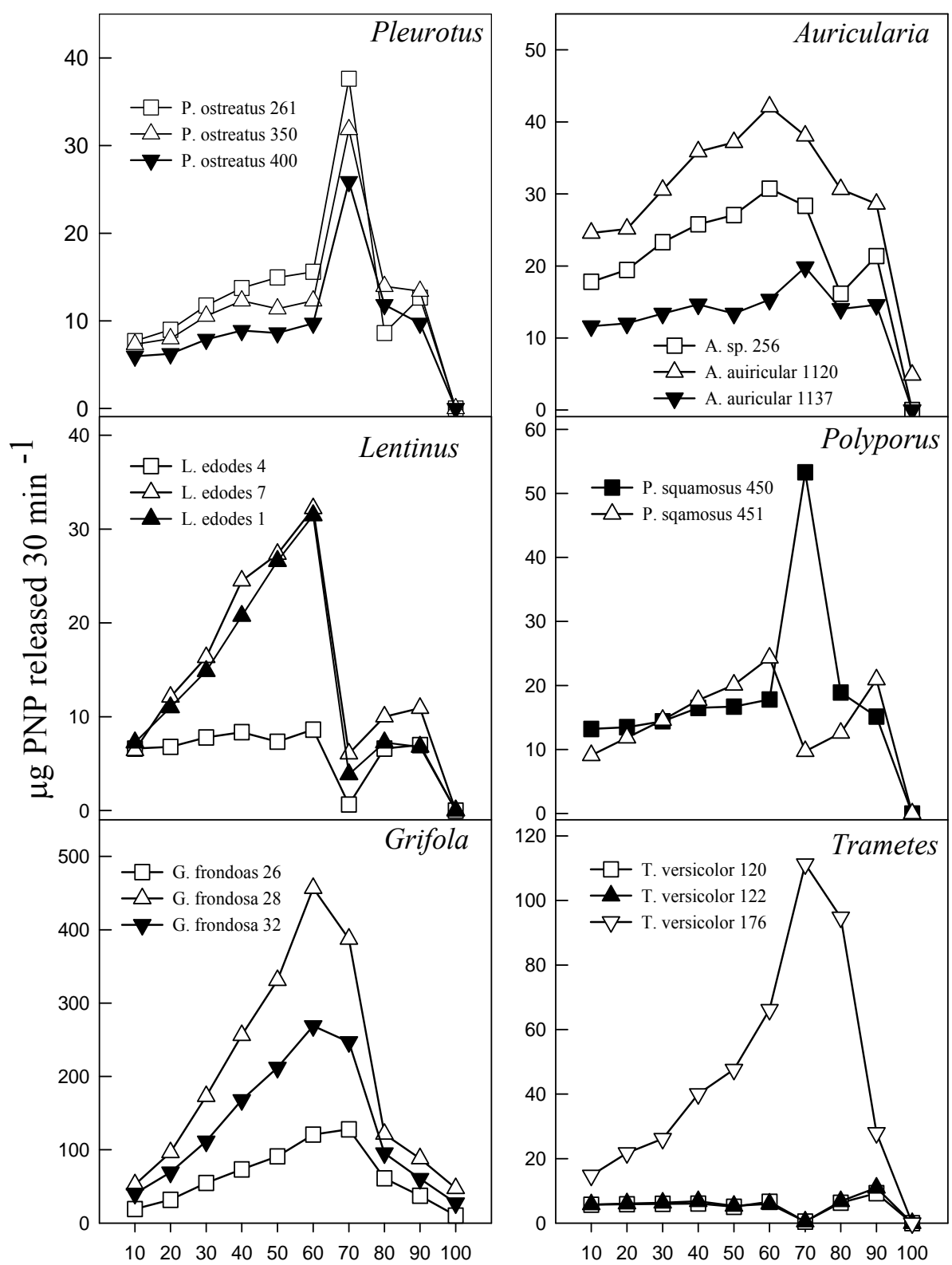

Temperature $\left({ }^{\circ} \mathrm{C}\right)$

Figure 2. Effect of temperature on $\beta$-glucosidase activities of various white rot fungi.

In this study, it was noted that the increase in product formed was relatively gradual with increasing temperature until the optimum temperature was reached, after which the enzyme denatured rapidly and consistently with the temperature profiles of other studies [33]. The activation energy $\left(E_{a}\right)$ or energy barrier that must be overcome for a reaction to proceed was estimated from the logarithmic transformed Arrhenius equation $(\log K=$ $\left.\left(-E_{a} / 2.303 \mathrm{RT}\right)+\log A\right)$. The values for Pleurotus, Auricularia and Grifola strains tested were generally similar, while those for Polyporus, Lentinula and Trametes showed significant differences (Figure 3). The calcu- lated $E_{a}$ ranged from as low as $1.5 \mathrm{~kJ} \cdot \mathrm{mol}^{-1}(T$. versicolor-120) to as high as $33.6 \mathrm{~kJ} \cdot \mathrm{mol}^{-1}$ (G. frondosa-28) with an average value of $16.0 \mathrm{~kJ} \cdot \mathrm{mol}^{-1}$ (Table 4). Generally, there is a doubling in reaction rate with every $10^{\circ} \mathrm{C}$ increase in temperature for chemical reactions known as the temperature coefficient or temperature quotient $\left(Q_{10}\right)$. However, this is not always the case with biological systems such as enzyme-catalyzed reactions where the $Q_{10}$ is generally in an order of magnitude $<2$ [34]. The estimated $Q_{10}$ values for the $\beta$-glucosidase activities ranged from 1.1 (Aricularia spp.) to $1.6(G$. frondosa-28) and were generally below 2.0 (Table 4). 
Table 4. Temperature coefficients $\left(Q_{10}\right)$ and activation energies $\left(E_{a}\right)$ of $\beta$-glucosidase activities of white rot fungi.

\begin{tabular}{cccc}
\hline Samples & Opt. Temp. $\left({ }^{\circ} \mathrm{C}\right)$ & $Q_{10}$ & $E_{a}\left(\mathrm{~kJ} \cdot \mathrm{mol}^{-1}\right)$ \\
\hline Pleurotus ostreatus-261 & $70(90)$ & 1.4 & 17.4 \\
Pleurotus ostreatus-350 & 70 & 1.4 & 1.1 \\
Pleurotus ostreatus-400 & 70 & 1.3 & 15.2 \\
Lentinula edodes-1 & $60(80,90)$ & 1.1 & 23.2 \\
Lentinula edodes-4 & $60(80,90)$ & 1.4 & 3.7 \\
Lentinula edodes-7 & $60(80,90)$ & 1.1 & 24.7 \\
Auricularia sp.-265 & 60 & 1.1 & 8.9 \\
Auricularia auricular-1120 & $60(90)$ & 1.1 & 9.0 \\
Auricularia auricular-1137 & 70 & 1.4 & 5.9 \\
Grifola frondosa-26 & 70 & 1.6 & 25.9 \\
Grifola frondosa-28 & 60 & 1.5 & 33.6 \\
Grifola frondosa-32 & 60 & 1.4 & 29.9 \\
Polyporus squamosus-450 & 70 & 1.2 & 13.6 \\
Polyporus squamosus-451 & $60(90)$ & 1.0 & 15.1 \\
Trametes versicolor -120 & 60 & 1.1 & 1.5 \\
Trametes versicolo-122 & 60 & 1.4 & 3.9 \\
Trametes versicolor -176 & 70 & & 25.5 \\
\hline
\end{tabular}

$Q_{10}=\frac{\beta-\text { glucosidase activity at } \mathrm{T}\left({ }^{\circ} \mathrm{C}\right)}{- \text { glucosidase activity at } \mathrm{T}\left({ }^{\circ} \mathrm{C}\right)-10^{\circ} \mathrm{C}}$.

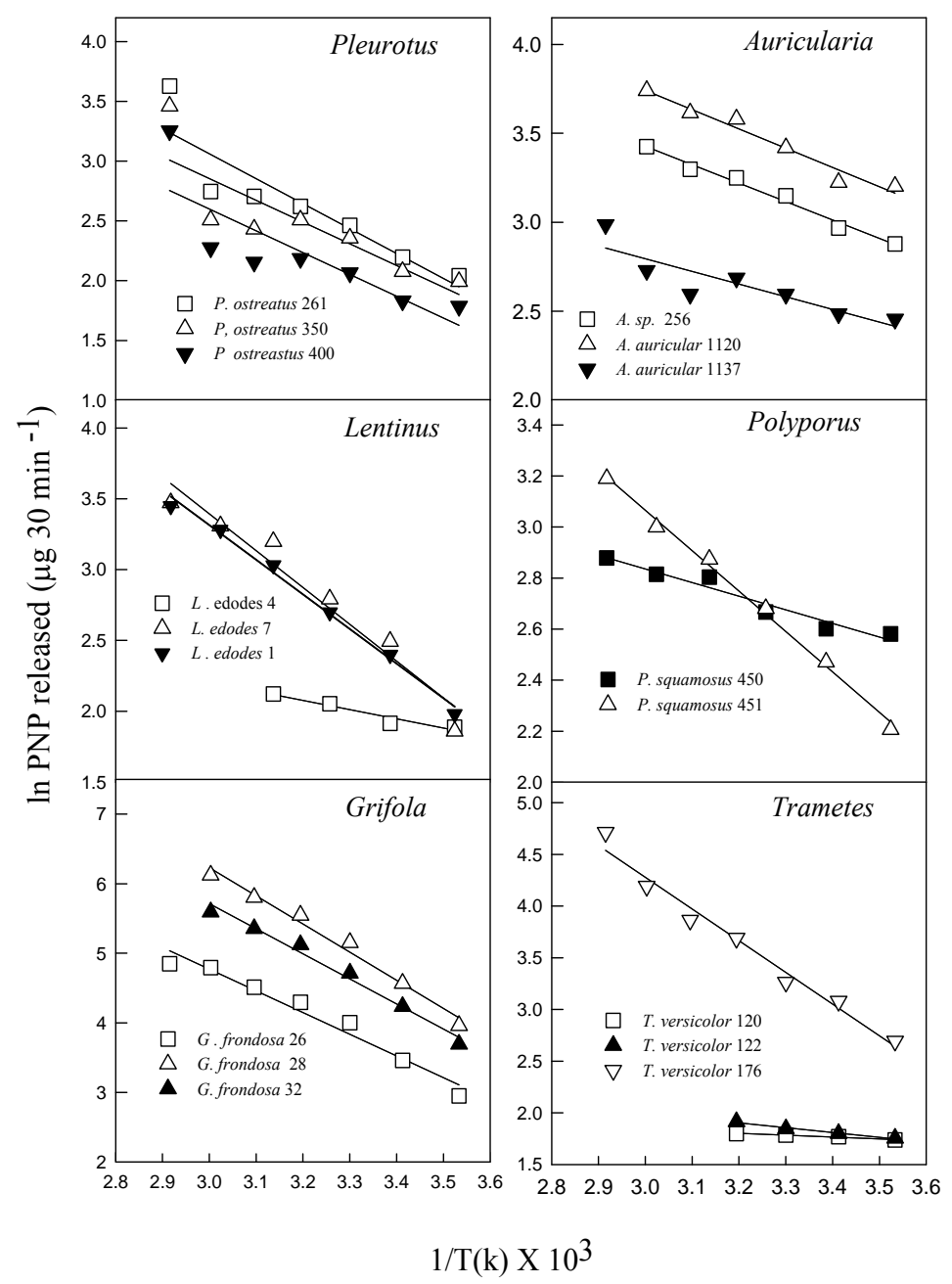

Figure 3. Arrhenius equation plot of $\beta$-glucosidase activities of various white rot fungi. 
Jabbar et al. [34] reported $Q_{10}$ of a purified cellulosehydrolyzing endoglucanase at 1.01 . This indicates that the reaction rates less than doubled for every $10^{\circ} \mathrm{C}$ increase in incubation temperature.

\section{CONCLUSION}

Significant quantitative and qualitative differences exist among the $\beta$-glucosidase activities of WRF. The enzymes also exhibited different response patterns to $\mathrm{pH}$ and incubation temperature conditions. Thus screening the WRF responsible for the biodegradation of most plant biomass for their $\beta$-glucosidase biocatalytic potentials offers an attractive tool for plant biomass transformation. If appropriately screened and purified, they can be harnessed to potentially improve the bioconversion of cellulose to glucose and also facilitate efficient plant biomass biodegradation to useful bio-products.

\section{ACKNOWLEDGEMENTS}

This work is a contribution of the Winfred Thomas Agricultural Research Station, Alabama A\&M University, Normal, AL. Trade or manufacturers' names mentioned are for information only and do not constitute endorsement, recommendation, or exclusion by Alabama A\&M University and collaborating universities. This research was supported in part by USDA, Evans-Allen Grant \# ALAX 011.

\section{REFERENCES}

[1] Barr, D.P. and Aust, S.D. (1994) Mechanisms white rot fungi use to degrade pollutants. Environmental Science and Technology, 28, 78A-87A.

[2] Wasser, S.P. (2002) Medicinal mushrooms as a source of antitumor and immunomodulating polysaccharides. Applied Microbiology and Biotechnology, 60, 258-274. doi:10.1007/s00253-002-1076-7

[3] Hadar, Y., Kerem, Z. and Gorodecki, B. (1993) Biodegradation of lignocellulosic agricultural wastes by Pleurotus ostreatus. Journal of Biotechnology, 30, 133-139. doi:10.1016/0168-1656(93)90034-K

[4] Isikhuemhen, O.S., Anoliefo, G.O. and Oghale, O.I. (2003) Bioremediation of crude oil polluted soil by the white rot fungus, Pleurotus tuberregium (Fr.) Sing. Environmental Science and Pollution Research, 10, 108-112. doi:10.1065/espr2002.04.114

[5] Bezalel, L., Hadar, Y. and Cerniglia, C.E. (1996) Mineralization of polycyclic aromatic hydrocarbons by the white rot fungus Pleurotus ostreatus. Applied and Environmental Microbiology, 62, 292-295.

[6] D’Annibale, A., Ricci, M., Leonardi, V., Quaratino, D., Mincione, E. and Petruccioli, M. (2005) Degradation of aromatic hydrocarbons by white rot fungi in a historically contaminated soil. Biotechnology and Bioengineering, 90, 723-731. doi:10.1002/bit.20461

[7] Mukherjee, R. and Nandi, B. (2004) Improvement of in vitro digestibility through biological treatment of water hyacinth biomass by two Pleurotus species. International Biodeterioration and Biodegradation, 53, 7-12. doi:10.1016/S0964-8305(03)00112-4

[8] D'Souza, T.M., Merrit, C.S. and Reddy, C.A. (1999) Lignin-modifying enzymes of the white rot basidiomycete Ganoderma lucidum. Applied and Environmental Microbiology, 65, 5307-5313.

[9] Heinzkill, M., Bech, L., Halkier, T., Schneider, P. and Anke, T. (1998) Characterization of laccases and peroxidases from wood-rotting fungi (family Coprinaceae). Applied and Environmental Microbiology, 64, 1601-1606.

[10] Isikhuemhen, O.S. and Mikiashvili, N.A. (2009) Lignocellulolytic enzymes activity, substrate utilization and mushroom yield by Pleurotus ostreatus cultivated on substrate containing anaerobic digester solids. Journal of Industrial Microbiology and Biotechnology, 36, 13531362. doi:10.1007/s10295-009-0620-1

[11] Isikhuemhen, O.S., Mikiashvili, N.A., Adenipekun, C.O., Ohimain, E. I. and Shahbazi, G. (2012) The tropical white rot fungus, Lentinus squarrosulus Mont.: Lignocellulolytic enzymes activities and sugar release from cornstalks under solid state fermentation. World Journal of Microbiology and Biotechnology, 28, 1961-1966. doi:10.1007/s11274-011-0998-6

[12] Das, M., Royer, T.V. and Leff, L.G. (2007) Diversity of fungi, bacteria, and actinomycetes on leaves decomposing in a stream. Applied and Environmental Microbiology, 73, 756-767. doi:10.1128/AEM.01170-06

[13] Yu, H., Zeng, G., Huang, H., Xi, X., Wang, R., Huang, D., Huang, G. and Li, J. (2007) Microbial community succession and lignocellulose degradation during agricultural waste composting. Biodegradation, 18, 793-802. doi:10.1007/s10532-007-9108-8

[14] Platt, M.W., Hadar, Y. and Chet, I. (1984) Fungal activities involved in lignocellulose degradation by pleurotus. Applied Microbiology and Biotechnology, 20, 150-154. doi:10.1007/BF00252594

[15] Berrin, J.G., Czjzek, M., Kroon, P.A., McLauchlan, W.R., Puigserver, A., Williamson, G. and Juge, N. (2003) Substrate (aglycone) specificity of human cytosolic betaglucosidase. Biochemical Journal, 373, 41-48. doi:10.1042/BJ20021876

[16] Kumar, R., Singh, S. and Singh, O.V. (2008) Bioconversion of lignocellulosic biomass: Biochemical and molecular perspectives. Journal of Industrial Microbiology and Biotechnology, 35, 377-391. doi:10.1007/s10295-008-0327-8

[17] Stockton, B.C., Mitchell, D.J., Grohmann, K. and Himmel, M.E. (1991) Optimum beta-d-glucosidase supplementation of cellulase for efficient conversion of cellulose to glucose. Biotechnology Letters, 13, 57-62. doi:10.1007/BF01033518

[18] Howell, J.A. and Stuck, J.D. (1975) Kinetics of solka floc cellulose hydrolysis by Trichoderma viride cellulase. Biotechnology and Bioengineering, 17, 873-893. doi:10.1002/bit.260170608

[19] Morais, H., Ramos, C., Forgacs, E., Jakab, A. and Cser- 
hati, T. (2004) Enzyme production of Pleurotus ostreatus evaluated by the three-way principal component analysis. Engineering in Life Sciences, 4, 165-170. doi:10.1002/elsc.200420017

[20] Cai, Z., Xing, G., Yan, X., Xu, H., Tsuruta, H., Yagi, K. and Minami, K. (1997) Methane and nitrous oxide emissions from rice paddy fields as affected by nitrogen fertilisers and water management. Plant and Soil, 196, 7-14. doi:10.1023/A:1004263405020

[21] Czjzek, M., Cicek, M., Zamboni, V., Burmeister, W.P., Bevan, D.R., Henrissat, B. and Esen, A. (2001) Crystal structure of a monocotyledon (maize ZMGlu1) beta-glucosidase and a model of its complex with $p$-nitrophenyl beta-D-thioglucoside. Biochemical Journal, 354, 37-46. doi:10.1042/0264-6021:3540037

[22] Langston, J., Sheehy, N. and Xu, F. (2006) Substrate specificity of Aspergillus oryzae family 3 beta-glucosidase. Biochimica Et Biophysica Acta-Proteins and Proteomics, 1764, 972-978. doi:10.1016/j.bbapap.2006.03.009

[23] Saha, A.K. and Brewer, C.F. (1994) Determination of the concentrations of oligosaccharides, complex type carbonyhdrates, and glycoproteins using the phenol-sulfuric acid method. Carbohydrate Research, 254, 157-167. doi:10.1016/0008-6215(94)84249-3

[24] Bradford, M.M. (1976) A rapid and sensitive method for the quantitation of microgram quantitites of protein utilizing the principle of protein-dye binding. Analytical Biochemistry, 72, 248-254. doi:10.1016/0003-2697(76)90527-3

[25] Szklarz, G.D., Antibus, R.K., Sinsabaugh, R.L. and Linkins, A.E. (1989) Production of phenol oxidases and peroxidases by wood-rotting fungi. Mycologia, 81, 234240. doi: $10.2307 / 3759705$

[26] Morais, H., Ramos, C., Forgacs, E., Cserhati, T., Oliviera, J. and Illes, T. (2001) Three-dimensional principal component analysis employed for the study of the beta-glucosidase production of Lentinus edodes strains. Chemometrics and Intelligent Laboratory Systems, 57, 57-64. doi:10.1016/S0169-7439(01)00121-6
[27] Ng, T.K. and Zeikus, J.G. (1981) Comparison of extracellular cellulase activities of clostridium-thermocellum-lqri and trichoderma-reesei-QM9414. Applied and Environmental Microbiology, 42, 231-240.

[28] Dick, W.A. and Tabatabai, M.A. (1984) Kinetic-parameters of phosphatases in soils and organic waste materials. Soil Science, 137, 7-15. doi:10.1097/00010694-198401000-00002

[29] Dowd, J.E. and Riggs, D.S. (1965) A comparison of estimates of Michaelis-Menten kinetic constants from various linear transformations. Journal Biological Chemistry, 240, 863-869.

[30] Cai, Y.J., Buswell, J.A. and Chang, S.T. (1998) Betaglucosidase components of the cellulolytic system of the edible straw mushroom, Volvariella volvacea. Enzyme and Microbial Technology, 22, 122-129. doi:10.1016/S0141-0229(97)00151-8

[31] Sun, Y.M., Zhang, Y.Z., Liu, N., Li, D.M. and Li, M.Z. (2010) Hydrolysis of genistin and daidzin by a beta-glucosidase purified from Lentinula edodes. Journal of Medicinal Plants Research, 4, 2684-2690.

[32] Parry, N.J., Beever, D.E., Owen, E., Vandenberghe, I., Van Beeumen, J. and Bhat, M.K. (2001) Biochemical characterization and mechanism of action of a thermostatble beta-glucosidase purified from Thermoascus aurantiacus. Biochemical Journal, 353, 117-127. doi:10.1042/0264-6021:3530117

[33] Gueguen, Y., Chemardin, P., Labrot, P., Arnaud, A. and Galzy, P. (1997) Purification and characterization of an intracellular beta-glucosidase from a new strain of $\mathrm{Leu}$ conostoc mesenteroides isolated from cassava. Journal of Applied Microbiology, 82, 469-476. doi:10.1046/j.1365-2672.1997.00136.x

[34] Jabbar, A., Rashid, M.H., Javed, M.R., Perveen, R. and Malana, M.A. (2008) Kinetics and thermodynamics of a novel endoglucanase (cmcase) from Gymnoascella $\mathrm{ci}^{-}$ trina produced under solid-state condition. Journal of Industrial Microbiology and Biotechnology, 35, 515-524. doi:10.1007/s10295-008-0310-4 